\title{
Karel SCHMEIDLER
}

\section{Stanovanjski trendi in trendi $v$ razvoju urbanizma v Češki republiki}

\begin{abstract}
Članek opisuje stanovanjske trende v Češki republiki. Določajo jih družbene, gospodarske, tehnične in kulturne spremembe, ki v zadnjih dveh desetletjih potekajo v srednji Evropi, in so hkrati pozitivni in negativni. Pozitivna trenda sta dvig količine ter kakovosti stanovanjskega prostora in raznolikost arhitekturnih rešitev za posamezne naročnike. Negativni trend pa je širitev urbanega prostora, ki skupaj s čedalje več avtomobili uničuje naravo ter prostor in manjša vrednost zemljišč. Razvoj je neizogiben, zato se je treba načrtovanja pokrivanja stanovanjskih potreb lotiti razumno in multidisciplinarno ter razumeti potrebe človeka in narave.
\end{abstract}

KLJUČNE BESEDE: stanovanjski trendi, staranje družbe, kakovost življenja, spremembe življenjskega sloga, suburbanizacija, družbene spremembe, kulturna določitev, nizke stanovanjske stavbe, družinske hiše.

\section{Uvod: Stanovanje - izvrsten človekov življenjski prostor}

Človekov poglavitni življenjski prostor je hiša ali stanovanje. Dom poskrbi za izpolnitev osnovnih (zagotavlja prostor za zadovoljitev fizioloških potreb, kakršne so spanje, prehranjevanje, počitek in skrb za družino), višjih (občutek pripadnosti, zadovoljitev potrebe po ustalitvi, potrebe po življenju v estetskem okolju itd.) in drugih človeških potreb. Dom s tem postane sredstvo in spodbuda za nadaljnji razvoj.

Dom ali stanovanje je eno izmed poglavitnih determinant kakovosti življenja. Vpliva na vse plati duševnega in socialnega zdravja. Kakovostno stanovanje spodbudno vpliva na duševni mir in družinsko življenje ter na dosežke na poklicni poti in $\mathrm{v}$ izobraževanju. Prav nasprotno pa velja, če človek živi v nekakovostnem stanovanju oziroma če ga nima. Potreba po stanovanjih se na Češkem povečuje zaradi velikih demografskih in družbenih sprememb, s katerimi se spoprijema češka družba, zato je treba odgovore za stanovanjska vprašanja v 21. stoletju iskati multidisciplinarno.
This article describes housing trends in Czech republic, which are determined by social, economic, technical and cultural changes of last two decades In Central Europe. Those trends have positive and also negative sides: positive can be seen the quantitative and qualitative growth of housing space, variety of architectural solutions for individualised customer. Negative aspect is urban sprawl, which together with individual automobile occupancy destroys nature, space and land values. Future development is inevitable, proper design of housing needs sensitive multidisciplinal attitude and understanding of the needs of man and nature.

KEY WORDS: housing trends, ageing of the society, quality of life, changes of the lifestyle, suburbanisation, social changes, cultural determination, low-rise city housing, family housing.

\section{Kakovost življenja in pomen stanovanja}

Bivanje je zapletena dejavnost, ki odseva tudi najmanjše spremembe $\mathrm{v}$ družbi, kulturi in tehnologiji. Stanovanje pomeni prostor za vse dejavnosti, ki potekajo doma. Dom ali stanovanje je splet med sabo povezanih sob, prostor z jasno določenimi mejami, ki posamezniku omogočajo trajno varnost. Splošni pojem stanovanje povzema vse vsakdanje družbene dejavnosti v prostoru, v katerem človek živi, in njegovo vedenje $\mathrm{v}$ tem prostoru. »... Stanovanje je oblika tvojega, mojega, našega obstoja, obstoja ljudi na Zemlji ..." (Heidegger, 2002) Glede na vrednote in koncepte naše kulture ga lahko opredelimo kot lokaliziran, zaseben in svoboden obstoj v prostoru, zgrajenem tako, da je ločen od okolice. Sociološke raziskave kažejo, da je zadovoljstvo $\mathrm{z}$ domom nujno za zadovoljitev vsega stanovanjskega okolja, v katerem živi človek. Dom je prostor, v katerem potekajo osnovni bivanjski procesi in $\mathrm{v}$ katerem se razvijajo najintenzivnejši čustveni odnosi. Če ne izpolni svojega namena, ne more človek nikjer najti zamenjave zanj in poiskati alternativne zadovoljitve potrebe po stanovanju. 


\section{Spremembe stanovanja in njegovih funkcij v 21. stoletju}

Stanovanje je bilo v preteklosti javen prostor. V predindustrijskem obdobju je imelo več funkcij. V njem so potekale tudi poklicne in prostočasne dejavnosti. Ljudje so se v njem sestajali z naročniki, bilo pa je tudi kraj druženja. V njem so potekali družabni dogodki in intimnejše dejavnosti. Zdaj pa je stanovanje predvsem zaseben prostor. Je dom za družino in njene člane. Družba je pomembne javne predstavitvene funkcije preselila drugam. Sestava skupine ljudi, ki živijo v stanovanju (največkrat je to družina), in funkcija stanovanja kot zasebnega življenjskega prostora sta temelja za uresničitev funkcionalnih zahtev, ki omogočajo različne življenjske sloge in oblike vedenja. Močna povezanost med funkcijami prostora in njegovimi stanovalci se izraža $\mathrm{v}$ procesu bivanja, zato se sociologija doma oziroma stanovanja posveča predvsem odnosu med življenjskim prostorom in njegovim uporabnikom ter njegovimi dejavnostmi in vedenju doma. To razmerje vključuje tehnične/ funkcionalne vidike, pogosto pa tudi družbene ter duševne vidike in potrebe. Življenje v stanovanju je zato družbena dejavnost, pri kateri v večini domov sodeluje več ljudi, največkrat družinskih članov. Življenje v stanovanju pomeni opravljanje zelo različnih družbenih dejavnosti in oblik vedenja, ki največkrat izražajo zasebnost, ločeno od vseh vplivov, ki so skupini v stanovanju tuji. Dom omogoča zasebnost, samoto, ločitev od drugih, a tudi druženje z drugimi, kadar si človek to želi in se za to odloči. Dom je privilegiran zaprt prostor za posameznika ali za majhno skupino oziroma družino, ki živi v skupnem gospodinjstvu. Razmejitev in ločenost od zunanje okolice omogočata človeku doseči občutek, da je v varnem okolju. Potreba po ustreznem stanovanju je ena izmed njegovih osnovnih potreb, zadovoljuje pa tudi številne višje potrebe. Dom zato pogosto opredeljujemo kot »okolje za zadovoljitev nekaterih človekovih potreb«. Navedimo vsaj nekaj izmed številnih primerov (Fürstenberg, 1974; Bahrdt, 1974): »... Družinsko stanovanje je umetno in funkcionalno ločen del materialnega in prostorskega okolja, dodeljenega določeni družbeni skupini, tj. družini, in namenjenega zadovoljitvi nekaterih potreb ljudi, ki živijo v družinski skupnosti ...«Zahteva po stanovanju izhaja iz potrebe po njem. Osnovne zahteve so preproste in očitne (potreba po zasebnem prostoru, toploti/zaščiti pred mrazom in vlago, po prostoru za kuhanje in prehranjevanje, po sanitarijah ...). Povezane so z biološkimi potrebami posameznika. Strinjam se s Chapmanom, ki pravi, da so druge stanovanjske potrebe $\mathrm{v}$ primerjavi z biološkimi sekundarne. Navezujejo se na prostore, ki omogočajo prostočasne dejavnosti. Povezane so tudi z drugimi, neotiplijivimi lastnostmi, kakršne so zasebnost, neodvisnost, varnost, družabni stiki, delo, izraz moči ali lastništva, družbenega položaja ... Doslej so bile v ospredju osnovne zahteve. $\mathrm{V}$ prihodnosti pa bo treba podrobneje razmisliti o sekundarnih zahtevah, povezanih s prostočasnimi dejavnostmi in priložnostmi za osebni razvoj, ki ga omogoča nemoteno izobraževanje. Kot je dejal Mitscherlich, kakovosti stanovanj ne bomo ugotavljali zgolj po tem, koliko lahko zadovoljijo naravne človekove potrebe, ampak bomo upoštevali tudi njihov družbeni pomen kot sredstvo za izražanje prestiža, koristnosti in moči.

\section{Stanovanje v 21. stoletju znova postane blago}

Stanovanje je tudi blago, tako kot na primer hrana. Je nosilec menjalne vrednosti, ker je v njegov razvoj vloženo človeško delo. Stanovanje ima uporabno vrednost, ki se izraža kot blago. Politiki so soglasni, da ima vsak človek pravico do ustreznega bivanjskega prostora. Prosti trg ne bo mogel nikoli povsem zadovoljiti povpraševanja po koristi, ki jo prinaša stanovanje, saj ima kot blago prav posebne lastnosti.

Za premostitev tega neskladja je treba oblikovati premišljeno stanovanjsko politiko. Opravičuje jo dejstvo, da je stanovanje ena izmed osnovnih človekovih potreb. Njena zadovoljitev je za družbo izjemno pomembna, saj močno vpliva na trdnost družine, na vzgojo in izobraževanje, posredno pa tudi na družbeno zavest, moralo posameznika in moralo družbe.

Družbene, gospodarske in kulturne spremembe $\mathrm{v}$ Češki republiki so se že pokazale tudi na področju stanovanj. V 90. letih prejšnjega stoletja so poudarjali ustvarjalno svobodo, mednarodne arhitekturne strokovnjake, raznolikost materialov in kakovost, čedalje večje posvečanje kupcem itd. Smernice so povzemali iz dobrih in slabih modelov. Se bo raZvoj v 21. stoletju nadaljeval $\mathrm{v}$ enaki smeri ali pa se potrebe družbe, povezane s stanovanji, tako zelo spreminjajo, da bo gradnja stanovanjskih blokov ubrala popolnoma drugo smer?

Politične in družbene spremembe v češki družbi so spremenile potrebe in zahteve, povezane s stanovanji. Dohodek prebivalstva se je spremenil - razlike so že zelo očitne - in privzeti novi modeli so spremenili življenjski slog. Velike spremembe se dogajajo tudi v socialni varnosti. Prav tako opažamo dinamične spremembe $\mathrm{v}$ sestavi in velikosti družine ter $\mathrm{v}$ demografskih kazalnikih, zato se je z vidika države spremenilo celo konceptualno razumevanje stanovanja. 
Vlada zdaj drugače razmišlja o svoji odgovornosti do državljanov. Ta premik lahko razumemo kot spremembo v stanovanjski politiki. Nekdanja država je zagotavljala stanovanja, zdaj pa ustvarja razmere za spodbujanje zasebnega lastništva stanovanj, pridobljenega z zasebnimi sredstvi (gradnja stanovanjskih blokov, stanovanjska posojila, stanovanjske varčevalne sheme itd.). Ta pristop so prvič uporabili $\mathrm{v} 70$. letih prejšnjega stoletja $v$ državah $s$ tržnim gospodarstvom (na primer v Angliji v obdobju Thatcherjeve). Zdaj prevladuje $\mathrm{v}$ razvijajočih se srednjeevropskih demokracijah. Državljani ne pričakujejo več od države, da jim bo priskrbela stanovanje, ampak da jim bo zagotovila ugodne razmere za gradnjo in nakup. To je povezano s čim svobodnejšim stanovanjskim trgom in z delovanjem demokratičnih načel $\mathrm{v}$ družbi. Vključuje tudi civilne iniciative, sodelovanje prebivalstva in decentralizacijo odločanja, vendar se ne omejuje le nanje. Taka stanovanjska politika omogoča vstop udeležencem, ki prej na tem področju niso bili dejavni, na primer civilnim organizacijam in volilnim enotam. Te strukture se posvečajo iskanju smiselnejših, uporabnejših in bolj usmerjenih rešitev za specifične stanovanjske težave posameznih skupin prebivalstva. Zasebniki zdaj več kot 40 odstotkov novih stanovanj kupijo zaradi oddajanja $\mathrm{v}$ najem in podnajem.

\section{Zmanjšanje količine in kakovostni dolg $\mathrm{v} 21$. stoletju}

Doslej se je napredek na področju stanovanj in stanovanjske gradnje zmanjševal. Češka ima najstarejša stanovanja v Uniji. Večina je starih več kot 50 let. V stavbnem fondu je novih samo pet odstotkov. Podatki nekdanje delniške družbe Terplan kažejo, da se je število stanovanj na sto prebivalcev med letoma 1991 in 1997 zmanjšalo, in sicer s 360 na 255. Za primerjavo - $\mathrm{v}$ istem obdobju se je število osebnih avtomobilov na Češkem potrojilo. Primanjkljaj je nastal zato, ker številne družine niso lastnice stanovanj in ker je stavbni fond starih in novih stanovanj na Češkem v primerjavi z Zahodom še vedno na zelo nizki ravni. Kar 26,6 odstotka jih je 3. in 4. kategorije, to pomeni s skupnimi sanitarijami brez vseh dodatkov oziroma brez vsakršnih dodatkov in opreme. V nekaterih zgodovinskih mestih je ta delež še veliko večji, kar 50-in celo večodstoten! Zahteve psihologov, sociologov in zdravstvenih delavcev po ločenem življenjskem prostoru za vsakega člana gospodinjstva še niso izpolnjene. Premalo letno zgrajenih stanovanj ostaja pomembna gospodarska značilnost razvoja Češke republike. Leta 1998 so bile zgrajene 15.904 stanovanjske enote oziroma 13,3 odstotka več kot v letu 1996. V primerjavi z letom 1989, v katerem je bilo zgrajenih 28,9 odstotka od tedanjih 55.073 stanovanj, se je število novogradenj zelo zmanjšalo. Na Češkem je bilo leta 2005 zgrajenih 3000 novih stanovanjskih enot, večinoma družinskih hiš. Povprečna velikost življenjskega prostora in povprečno število bivalnih prostorov na stanovanje sta razmeroma majhna. Po statističnih podatkih je leta 1996 povprečen bivalni prostor novih stanovanj meril 86,7 $\mathrm{m}$, povprečno število sob je bilo 3,1, povprečna velikost sobe pa $22 \mathrm{~m}^{2}$. Leta 2006 je bila povprečna velikost bivalnega prostora na človeka na Češkem 28, v Evropski uniji pa $35 \mathrm{~m}^{2}$. Najnovejši statistični podatki o stanovanjih v evropskih državah kažejo, da največji bivalni prostor $\mathrm{v}$ novih stanovanjih ponujajo v Belgiji, v povprečju kar $134,5 \mathrm{~m}^{2}$. Sledita ji Norveška s $128 \mathrm{~m}^{2}$ in Ciper s 133,7 m². V Avstriji, sosedi Češke, meri bivanjski prostor na človeka $92,2 \mathrm{~m}^{2}$.

Glavna značilnost gradnje novih stanovanj je arhitekturna struktura. Do začetka 90. let prejšnjega stoletja je bilo kar 70 odstotkov novih stanovanj v stanovanjskih blokih. Zdaj je ta delež precej manjši. Povečanje deleža drugih stanovanjskih oblik je posledica gradnje samostojnih družinskih hiš. V njih živi približno 46 odstotkov prebivalcev. Velikost najemniških stanovanj je ostala nespremenjena ( $45 \mathrm{~m}$ bivalnih prostorov), toda sob je manj. Ti kazalniki so pri družinskih hišah precej drugačni. Površina sob novih družinskih hiš, ki jih gradijo bodoči lastniki, je bila vedno večja od površin sob v stanovanjih $\mathrm{v}$ stanovanjskih blokih, vendar zdaj tudi to ne drži več. Značilnost zdaj grajenih hiš je dvakrat več sob in bivanjskih površin na stanovanje v družinski hiši, medtem ko je velikost posameznih sob in bivalne površine ostala enaka kot v stanovanjih v stanovanjskih blokih.

Sociologi, demografi, psihologi in ekonomisti že dolgo opozarjajo, da večina Čehov ni zadovoljna s svojim načinom življenja. Izsledki raziskave, ki jo je opravilo podjetje Terplan (Jiřina Čalfová, 1998), kaže, da je samo 5,5 odstotka mladih zakonskih parov opisalo svoje življenjske razmere kot zelo dobre, 40,6 odstotka kot dobre, 28,8 odstotka parov je izpostavilo pomanjkanje življenjskega prostora in slabe življenjske razmere, 24,7 odstotka parov pa je menilo, da živijo v popolnoma nesprejemljivih razmerah. Samo po sebi ni to nič nenavadnega - Evropejci so znani po kritičnosti in enako meni večina prebivalcev Srednje Evrope. Težava Čehov je v tem, da se večina ne more sprijazniti z mislijo o povsem spremenjenem načinu življenja. Večina preprosto nima denarja, da bi lahko izboljšala svoje življenjske razmere. Največ nezadovoljnih stanovalcev je v starostni skupini od 25 do 35 let. $V$ tej se nezadovoljstvo še krepi.

Prehod s stanovanjskega fonda na tržno gospodarstvo zamuja. Približno 17 odstotkov državljanov živi 
v stanovanjih z zakonsko določeno najemnino. Številni ekonomisti, sociologi in arhitekti menijo, da bi gradnjo stanovanj lahko spodbudili s popolno odpravo zakonskega določanja višine najemnin, saj bi to spodbudilo spremembe $v$ razrezu stroškov gospodinjstva v potrošniški košarici. Ker se države s povsem razvito tržno ekonomijo veliko hitreje in prožneje odzivajo na potrebe družbe na stanovanjskem področju (največkrat uporabljena metoda je prenova stanovanjskih blokov), jim uspeva preprečevati razvrednotenje stavbnega fonda in nepremičnin. Medtem ko v Zahodni Evropi in Ameriki prevladuje model mobilnih državljanov, ki brez denarnih težav na poti v službo in domov redno prepotujejo več kot 50 kilometrov na dan, pa ta model na Češkem ni uveljavljen. Razen majhne skupine ljudi z visokim dohodkom, ki se vozijo v službo s svojim avtom, je to za večino Čehov ekonomsko še vedno neizvedljivo.

\section{Uspeh projekta bo odvisen od kupcev in analize trga}

Vstopamo v obdobje, v katerem bodo ustreznost, kakovost in ekonomija gradnje stanovanj odvisne od kakovosti uvodnega projekta, projekta, priprave in izvedbe. Pri pripravah na uvodni projekt in projekt je treba preučiti vrsto pogojev in njihov vpliv na arhitekturo novih stavb. Izluščila sta se dva svetovna megatrenda - družbeni, ki ga določajo spremembe v demografski strukturi (staranje prebivalstva, čedalje več nuklearnih družin in samskih ljudi itd.), in tehnološki, ki ga določa eksponentno naraščajoča hitrost tehnoloških inovacij.

\section{Demografske, družbene in kulturne spremembe, ki vplivajo na stanovanja}

Demografske spremembe so v zadnjem desetletju prisilile arhitekte, urbaniste in politike, da znova razmislijo o konceptu stanovanja, primernega času in spremenjenim razmeram. Češka družina se je v zadnjem času zelo spremenila. V marsičem so prevzeli modele, ki so se uveljavili v Zahodni Evropi. Velike spremembe zasledimo tudi v velikosti in trdnosti nuklearne družine. Značilno gospodinjstvo z obema od staršev z otroki na Češkem počasi izpodrivajo samski ljudje (njihovo število se je v zadnjem času v Zahodni Evropi zelo povečalo), samohranilke oziroma samohranilci $z$ enim otrokom ali več in neporočeni pari. Model nuklearne družine, v kateri oče skrbi za sredstva za preživljanje družine, mati pa za otroke, kliše iz 50. let prejšnjega stoletja, ni več prevladujoči model družine. Čedalje več je samohranilskih družin.
Med samohranilci prevladujejo ženske. Čedalje več je tudi parov brez otrok in družin, v katerih hodita v službo oba od staršev. V veliko družinah ostanejo odrasli otroci doma, ker ne morejo najti svojega stanovanja in/ali ga plačevati. Povečuje se tudi število rešitev, ki so bile prej redke - med njimi naj omenim podeželske družine s starimi starši, ki se preselijo v mesto in ustvarijo mestne nuklearne družine.

Ti trendi bodo zelo pomembni za gradnjo stanovanj v prihodnosti. Napovedi za prebivalstvo Češke kažejo, da se hitro povečuje število gospodinjstev, ki se ne odzivajo na hitrost rasti prebivalstva; to je $\mathrm{v}$ nasprotju s trendom iz 90. let prejšnjega stoletja, za katerega je bila značilna stagnacija oziroma celo zmerno zmanjšanje števila prebivalstva $\mathrm{v}$ nekaterih regijah in obdobjih. Povprečna velikost gospodinjstev in družin se še naprej zmanjšuje. Največje nihanje $v$ povečevanju števila gospodinjstev pričakujemo po 1. 2010, ko naj bi naraslo za 109.800. Temu bodo sledila manjša povečanja. Povprečna velikost gospodinjstva se bo zmanjšala zaradi odhodov družinskih članov - mladi se bodo hitreje osamosvojili, več bo ločitev, znižala se bo starost ob sklenitvi zakonske zveze, načrti za otroke bodo preloženi na poznejši čas. V novem tisočletju bodo ženske rodile prvega otroka v 34. letu ali pozneje (Melany Howard, Future Foundation, Velika Britanija). Čehi so na tem področju že prevzeli zahodni model. Te spremembe bodo v prihodnosti še izrazitejše. Melany Howard iz angleške raziskovalne organizacije Future Foundation napoveduje, da bo zakonska zveza $\mathrm{v}$ prihodnosti izgubila pomen. Nadomestilo jo bo več partnerjev; precej pogoste bodo tri zakonske zveze v življenju. Profesor Richard Scase z Univerze v Kentu podpira svoje napovedi z izsledki raziskave, ki preučuje spreminjajoče se družbene strukture $z$ manj poročenimi pari in čedalje več ločenci (stopnja ločitev na Češkem je že zdaj 60-odstotna); čedalje več odraslih pa bo živelo brez partnerja. To bo seveda vplivalo na strukturo stanovanj, med katerimi še vedno primanjkujejo stanovanja za izobražene in bogate samske ljudi.

Uporabniške skupine se povečujejo. To vpliva na arhitekturno ustvarjalnost pri stanovanjskih projektih. Ena izmed skupin je starajoče se prebivalstvo. Zlasti v evropskih industrijskih državah narašča odstotek starejših ljudi. To je znano dejstvo. Napredek $\mathrm{v}$ medicini in javna higiena, bolj zdravo življenje, spremembe $\mathrm{v}$ naravi dela in proizvodnih tehnikah omogočajo daljšo pričakovano življenjsko dobo. Analitiki britanske Future Foundation napovedujejo, da bo v prihodnosti mogoče živeti 120 let. Po letu 2000 zasledimo veliko več ljudi v skupini nad 65 let. Zanje so značilni omejena mobilnost, čedalje večja odvisnost od drugih, geriatrični način življenja itd. Sociologi so začeli velikim mestom praviti geta 
starostnikov. Število ljudi, ki živijo sami, se bo povečalo za do 40 odstotkov. Finančni položaj starejše generacije je boljši, kot je bil v preteklosti. Starost ob upokojitvi se bo najverjetneje povišala. Nekatere britanske raziskave omenjajo, da se bodo ljudje $\mathrm{v}$ prihodnosti upokojevali pri 80 letih ter da bodo na svoji poklicni poti zamenjali od dva do tri poklice. To bo vplivalo tudi na stanovanjsko področje. Delež majhnih gospodinjstev z enim članom ali dvema se bo povečal na 50 odstotkov, napovedujejo demografi. Povečanje, čeprav ne tako hitro, pričakujejo tudi v številu gospodinjstev z dvema članoma ali več.

\section{Stanovanja po meri uporabnikov - prevoz, družbene in demografske determinante napredka na stanovanjskem področju}

Novim razmeram se morata prilagoditi tudi arhitekturni in urbani razvoj. Povpraševanje po kakovostnih stanovanjih se povečuje in se bo še naprej. Razmere na stanovanjskem trgu določa kakovostna priprava visokokakovostnih gradbenih programov za izbrane vrste stanovanj. Ti programi bi morali temeljiti na obsežnem poznavanju stanovanjskih funkcij za posamezna gospodinjstva, specifikaciji količinskih zahtev in ustreznih domnevah o potrebah.

Stanovanjske zahteve se spreminjajo s spreminjajočimi se vrednotami prihodnjih uporabnikov. To bo zelo spremenilo proces načrtovanja. Izsledki empirične raziskave Inštituta za urbani razvoj na Fakulteti za arhitekturo Češke Tehniške univerze za leti 1998 in 1999 so pokazale, kaj je pri prihodnjem stanovanju najpomembneje za anketirance (seznam po padajoči pomembnosti):

- ekonomski vidiki: varčnost in preprostost,

- tehnični standardi, brezhibnost, funkcionalnost, učinkovit tloris in dobra oprema,

- čisto in zdravo življenjsko okolje,

- estetski vidik bivalnega okolja, čeprav so odgovori temeljili na drugačnih izhodiščih - nekateri anketiranci so imeli raje stara, nekateri pa sodobna stanovanja,

- udobnost in preprosto vzdrževanje, preprosto čiščenje,

- prestižni znaki in simboli uspeha kot sredstva samoprepoznavnosti in dokazi uspeha: dve ali tri garaže, steklenjaki in zastekljeni vrtovi, zgodovinske oblike streh in arhitekturni detajli, razkošne kopalnice, kamini, savne in bazeni,

- prijetnost in prijaznost okolja,

- kombinacija vsega naštetega.

\section{Tehnične in tehnološke spremembe}

Na način življenja vplivajo tudi spremembe $\mathrm{v}$ tehniki in tehnologiji, delu, življenjskem slogu itd. Metode dela bodo zaradi znanstvenega in tehnološkega napredka najverjetneje zelo spremenile in splošna intenzifikacija dela bo večja. To se bo izrazilo tudi v drugačnih stanovanjskih potrebah. Povečal se bo delež aktivnosti, procesov in poklicev, ki zahtevajo večjo intelektualno vsebino, večjo usposobljenost in daljše priprave, zato bodo večje tudi zahteve po zbranosti, odgovornosti in ustvarjalni pobudi. V nekaterih kategorijah se bo število ur, povezanih $z$ delovnimi dejavnostmi, zmanjšalo, medtem ko se bo $\mathrm{v}$ drugih dolžina delovnega časa podaljšala. ${ }^{[1]}$ Nekaterim zaposlenim se bo delovni teden zaradi tako pridobljenega časa skrajšal, zato se bo povečalo povpraševanje po prostočasnih dejavnostih, ki se izvajajo doma. S tem se bo pomen doma in dejavnosti, ki potekajo v njem, še povečal. Posledici teh sprememb pa bosta tudi večji duševni stres in hiperstimulacija. Stres povzročajo delovne zahteve, pred katere so postavljeni više usposobljeni prebivalci, zlasti tisti na vodilnih položajih. Tržno gospodarstvo je povezano $z$ različnimi dejavniki tveganja. Zahodni psihologi in psihiatri opozarjajo na visoko stopnjo živčnega stresa pri poslovnežih in strokovnjakih. Ta obremenjenost ogroža trdnost družine, slabo pa vpliva tudi na okolje, zato se bo povečala potreba po izravnavanju prevelikih obremenitev telesa zaradi dela, zlasti dela od doma. Družina bo morala biti zavarovana pred stresom, ki ga povzroča delo, in prenasičenostjo z informacijami. Dom bo čedalje bolj postajal prostor, ki zagotavlja razmere za družinsko življenje in zasebnost, prostor, ki omogoča spontano in selektivno komunikacijo, telesno in duševno prenovo in sprostitev po delu, priprave na delo in izvajanje ustvarjalnih dejavnosti.

\section{Računalniška tehnologija in delo na domu}

Za drugi megatrend je značilen napredek $\mathrm{v}$ računalniški tehnologiji in prenosu podatkov v različnih oblikah, ki ga omogoča svetovni splet in ki ga tako rada omenjajo množična občila, vendar je to le eden izmed številnih vidikov. Med najhitreje razvijajočimi se dejavnostmi so različne oblike telekomunikacij, zbiranje in obdelava podatkov, bliskovit razvoj čipov, strojne in programske opreme ter svetovnega spleta. Ta napredek se na področju dela in bivanja uveljavlja veliko hitreje kot demografske spremembe. ${ }^{[2]}$ Zdajšnji napredek komunikacijskih tehnologij 
omogoča telekomunikacije številnim poklicem. Ker ljudem ni treba več hoditi v pisarne, se svet dela spreminja. Javni prostor postaja nejasen in manj čutno zaznaven, saj se je združil z računalniškimi mrežami, modemi, mobilnimi telefoni, videofoni in faksi. Informatiki pravijo temu prostoru tudi hiperprostor. Njegov obseg se bo še povečal, zlasti v razvitih državah. Profesorica Katharine Rosenberry z Univerze v San Diegu v Kaliforniji preučuje zakonske vidike poselitve. Napoveduje, da bo že leta 2014 do 80 odstotkov Američanov, zlasti tistih z višjo izobrazbo, delalo od doma, prek povezav $z$ informacijskimi in komunikacijskimi mrežami. Tudi profesor Richard Scase z Univerze v Essexu po izsledkih raziskave, ki jo je naredil, sklepa, da bo strokovno osebje delalo polovico delovnega časa doma ter da bo več zaposlenih za polovični in določeni delovni čas ter zasebnikov, samozaposlenih in pogodbenih delavcev. Profesor urbanističnega razvoja Sakkie Badenhorst iz Pretorije že zdaj opaža, da se je v številnih poklicih znatno povečal obseg dela od doma. Delo v stanovanjskih poslopjih omogočajo računalniške mrežne povezave. Delovne dejavnosti ljudi, zlasti tistih $\mathrm{z}$ visoko izobrazbo in strokovno usposobljenostjo, so se preselile $\mathrm{v}$ prijetna predmestja, kjer je gradnja cenejša, prostor za parkiranje pa neomejen. Spremembe odnosov na področju dela, ki so jih spodbudile nove tehnologije, bodo zelo vplivale na prostorsko ločitev prostora dela in prostora bivanja. Bliskovit razvoj računalniške tehnologije, ki je ustvaril povpraševanje po gradnji informacijskih avtocest, kaže, da lahko delo od doma z računalnikom, povezanim $z$ računalniško mrežo, odpravi številne negativne pojave sodobne civilizacije. Več sto tisoč ljudem se ne bo treba več voziti v službo, delati gneče na cestah in ulicah, porabljati goriva in onesnaževati okolja. Prevoz ljudi po cestah in ulicah ne bo več potreben, saj ga bo nadomestil prenos podatkov po žičnih in brezžičnih satelitskih povezavah. Podatki pa lahko potujejo brez bencina in ne potrebujejo fizičnega prostora tako kot cestna vozila, vlaki in letala. Poleg tega potujejo s svetlobno hitrostjo. Tega za javna prevozna sredstva nikakor ne moremo trditi. Številni ljudje bodo veseli, da jim ne bo treba več živeti blizu podjetja, v katerem so zaposleni, $\mathrm{v}$ prenatrpanem mestnem okolju ali $\mathrm{v}$ grdem stanovanjskem naselju $v$ onesnaženem okolju. Naselili se bodo lahko tako rekoč kjerkoli, kjer bodo hoteli. Velika betonska spalna naselja bodo zamenjale podeželske zgradbe, posejane na zelenih površinah. Hkrati s tem se bo morda vrnil tudi opuščeni model družine, v katerem vsi družinski člani živijo in delajo skupaj, v katerem so starši lahko blizu otrok in preživljajo čas z njimi, otroci pa lahko opazujejo starše pri delu in se tako pasivno pripravljajo na svojo poklicno pot. To bo morda znižalo tudi stopnjo ločitev, zmanjšalo obseg mladostnega prestopništva, zasvojenosti z mamili in ublažilo še številne druge môre sodobnega sveta. Strokovnjaki menijo, da so računalniške mreže in svetovni splet šele $\mathrm{v}$ povojih, da trenutno uporabljamo samo petino možnih aplikacij. Preostale štiri petine so še na voljo za domačo uporabo. To po povečalo povpraševanje po ergonomiji domačega delovnega okolja.

Elektronika in računalniki bodo spremenili stanovanja, saj bodo omogočili delo in tudi študij od doma (Pic-Tel ali e-učenje). Izobrazba se bo zvišala, saj se bodo ljudje učili vse življenje. Mrežna povezava $\mathrm{v}$ stanovanju je idealen pripomoček za to. Vstopamo v internetno dobo. $Z$ medmrežjem je povezanih več kot 200 milijonov ljudi z vsega sveta. Število dokumentov na svetovnem spletu se vsak dan poveča za milijon. Leta 2002 je bilo na svetovni računalniški mreži že več kot osem milijard dokumentov. Dom in stanovanje bosta spet postala ustrezen prostor za preživljanje prostega časa, rekreacijo, izobraževanje in kulturo.

\section{Razlike v stanovanjih}

V 90. letih prejšnjega stoletja se je začela močno poglabljati razlika $\mathrm{v}$ stanovanjskih potrebah in zahtevah posameznih skupin gospodinjstev po kakovosti življenja (velikost stanovanja, tloris, kakovost okolja itd.). Upravičeno lahko domnevamo, da se bo pritisk še nadaljeval, in sicer zaradi prehoda nekaterih gospodinjstev v višji dohodkovni razred in zaradi čedalje večjih razlik med posameznimi dohodkovnimi skupinami. Po pričakovanjih naj bi družine namenile več dohodka za pridobitev stanovanja in izboljšanje kakovosti bivališča. Spremembe v porazdelitvi povpraševanja in potreb bodo odsevale spremembe $\mathrm{v}$ družbeni in strokovni strukturi prebivalstva. Posamezne oblike in lastnosti stanovanjskega razvoja bodo bolj priljubljene kot druge. Kljub pričakovanemu dvigu najemnin na komercialne (s čimer se nenehno odlaša), se pojavlja občutno večje povpraševanje po več večjih prostorov, večji skladiščni zmogljivosti ter boljši zasnovi stanovanja in kakovosti širšega stanovanjskega okolja (zasebnost, estetski vidik, družbeno okolje itd.). Ljudje iz najvišjih dohodkovnih razredov so postali pionirji selitve $v$ predmestja. Za stanovanjske zgradbe $v$ predmestju je še zdaj značilno, da so zgrajene v ekološko prijaznejši okolici velikih mest. Zgradili in naselili so jih japiji, mladi, izobraženi, zelo mobilni in bogati ljudje, ki si lahko privoščijo privilegirano življenje. Sestava predmestnih prebivalcev je skoraj povsem homogena. Imajo bivališče $\mathrm{z}$ velikim vrtom blizu narave, vendar ohranjajo stalen stik z mestom. Bivališča imajo značilne znake individualizma in gmotnega bogastva - zasebne bazene, ki so po možnosti ogrevani, steklenjake in zimske vrtove, drage avtomobile, 
dvojne garaže itd. To vsekakor vpliva na življenjski slog njihovih uporabnikov. Družbena ekskluzivnost pa včasih pomeni, da ti ljudje uporabljajo dom le za spalnico, saj so skrajno obremenjeni z delom. Družbena razslojitev pa lahko zaneti napetost med uspevajočo manjšino in večino prebivalstva.

\section{Družinske hiše}

Stanovanjski bloki, alternativa samostojnim družinskim hišam, pogosto ne veljajo za idealen kraj za družinsko življenje. Lastna ali družinska hiša se zdi družinam še vedno idealna. Izsledki različnih mednarodnih raziskav, tudi čeških, v katerih so sodelovali anketiranci iz različnih socialnih in dohodkovnih skupin, so potrdili, da je ljudem bolj pri srcu družinska hiša z omejenim številom nadstropij (glej Cooper, 1972; Knorr-Siedow, 1999; in druge). Na začetku leta 1995 je AMASIA, agencija za trženje in analize socialnih informacij, anketirala vzorčno skupino Čehov, da bi ugotovila, kaj si mislijo o svojih stanovanjskih razmerah in kaj bi bilo treba narediti, da bi se izboljšale. Izsledki so pokazali, da si večina (58 odstotkov anketirancev) želi živeti v samostojni družinski hiši v predmestju, do 30 kilometrov od mestnega središča. V Nemčiji je imelo tako željo 87 odstotkov, v Avstriji (raziskava iz leta 1999) pa 73 odstotkov ljudi. V družinski hiši si želi živeti več kot polovica prebivalstva, ne glede na starost, območje in velikost kraja bivanja. Celo starejšim je ljubša pritlična hiša na
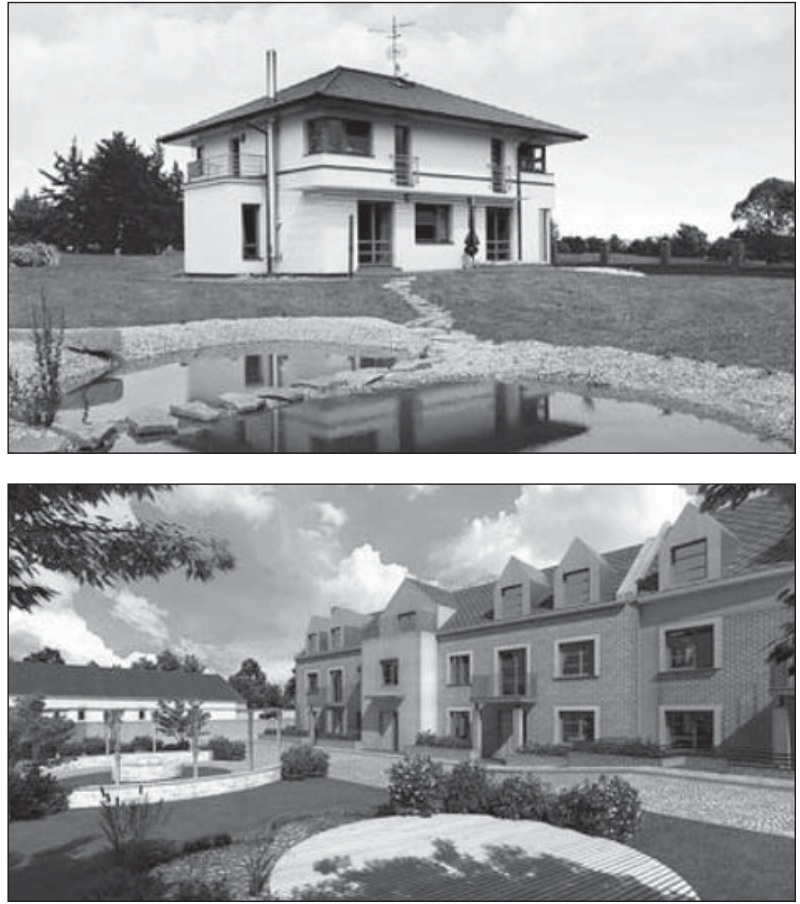

Slika 1: Samostojne družinske hiše so najhitreje rastoči stanovanjski sektor na Češkem. Povzročajo rast naselij in številne s tem povezane negativne posledice. obrobju mesta $\mathrm{z}$ dobrimi prometnimi povezavami s središčem mesta. Izsledki raziskave, v kateri so sodelovali prebivalci večnadstropnih blokov, so pokazali, da je tudi zanje družinska hiša idealen dom (Michelson, 1968). Jiřina Čalfová je leta 1998 s sociološkim sondiranjem mladih zakonskih parov in njihovih življenjskih razmer ugotovila enako. Raziskava je potekala $\mathrm{v}$ petih različno velikih mestih $\mathrm{z}$ različnim geografskim položajem: Pardubice, Přerov, Jablonec nad Nisou, Sušice in Hostinné. Mladi zakonski pari bi najraje živeli v svoji družinski hiši (58,4 odstotka), v stanovanju v bloku (20,1 odstotka), v družbenem stanovanju (12,3 odstotka) in v zadružnem stanovanju (7,3 odstotka). Zelo malo zanimanja je bilo za zadružna (samo 0,5 odstotka) in socialna stanovanja (0 odstotkov). Izsledki so jasno pokazali, da si ljudje želijo lastno stanovanje - tako se jih je opredelilo skoraj 80 odstotkov. Anketiranci so imeli raje družinske hiše kot stanovanja. Za družbeno stanovanje so se odločili le redki, nihče pa za socialno, to je za poceni stanovanje $z$ nizko najemnino. Podobne podatke so dobili v sosednji Avstriji. Po podatkih Hermanna Reinninga z Urada za načrtovanje Spodnje Avstrije bi v lastni družinski hiši najraje živelo 73 odstotkov prebivalcev te regije, 17 odstotkov jih je želelo biti lastnik stanovanja $\mathrm{v}$ bloku, v najetem stanovanju v hiši pa je želelo živeti le 10 odstotkov ljudi.

\section{Funkcionalna vsebina stanovanja}

Vsi izmed prej omenjenih trendov bodo v prihodnosti prispevali k obogatitvi funkcionalne vsebine stanovanja. To bo prizorišče različnih dejavnosti. Individualne funkcije doma bodo višje. To bo odvisno od tega, kako se bo na hierarhični lestvici vrednot prebivalstva (uporabnikov stanovanj) spreminjal položaj funkcij. Sprememba hierarhije vrednot bo zahtevala drugačen tloris in splošen dvig standardov stanovanjskega okolja (delovna soba, ki je značilna za inteligenco). Nove vrste hiš bodo omogočale uporabo nebivalnih in bivalnih območij $\mathrm{v}$ hiši. Povečalo se bo območje stanovanjskih in gospodinjskih delovnih prostorov. Potreba po tem se bo pojavila zaradi čedalje različnejših dejavnosti posameznih članov gospodinjstva in zaradi višjih strokovnih, sanitarnih in duševnih zahtev. Povečalo se bo število dragih predmetov, namenjenih dolgotrajni uporabi. To potrebo bosta preoblikovala večje število in velikost sob in skladiščnih prostorov. Tloris in tehnologija gospodinjstva bosta oblikovana tako, da bosta zagotovila čim manjšo izgubo časa zaradi gospodinjskih opravil. Čedalje več bo kakovostnih prenov stanovanj (boljša zaščita pred zunanjim hrupom, boljša naravna osvetljenost, klimatizirani prostori, uporaba odprtega prostora oz. 
atrija, izboljšanje sanitarne opreme). Nabor stanovanj bo dopolnjen s stanovanji za specifične skupine prebivalstva, ki so čedalje številnejše (samski, starostniki, invalidi itd.)

\section{Nizke stanovanjske stavbe}

Več bo pripadnikov srednjega razreda. Ni verjetno, da se bodo ljudje množično selili nazaj v mestna središča. Verjetnejša je gradnja vilskih četrti na obrobju mest. Namesto velikih stanovanjskih naselij zdaj gradijo v predmestjih, in sicer družinske hiše, ki so v lasti najuspešnejšega dela prebivalstva in tistih, ki so jim z denacionalizacijo vrnili zaseženo premoženje. Številni srednji razred, ki v nasprotju s predstavniki srednjega razreda $\mathrm{v}$ drugih evropskih državah na Češkem ni finančno močen, še vedno čaka na rešitev svojega stanovanjskega položaja. Lahko pa pričakujemo, da se bo gradnja po rešitvi težav s financiranjem gradnje stanovanj za srednji razred usmerila $\mathrm{v}$ nizke mestne hiše, primerne $\mathrm{za}$ načrtovana predmestja. Nizke stanovanjske stavbe so nujne za uresničitev stanovanjskih načrtov srednjega razreda. Temeljijo na zamisli, ki združuje ekonomske prednosti stanovanjskih blokov ter udobje in višji standard naravnega okolja družinskih hiš. Velika prednost nizkih stavb je, da so primerne za različne vrste okolja. Tako je mogoče stanovanja prilagoditi različnim družbenim razredom in poklicem stanovalcev. Ponujajo pa tudi rešitve za različna prostorska merila in različno opremo ter za preobrazbo stanovanja, ki se prilagaja spremenjenim potrebam družine.

Nove gospodarske in družbene razmere zahtevajo razumno uporabo vseh vrst nizkih stavb, kakršni so stanovanjski bloki za mestna središča in obrobja, večnamenski stanovanjski bloki, združeni s socialnimi storitvami (odvisno od značilnosti lokacije), stanovanjski bloki za specifične skupine prebivalstva (npr. hiše $\mathrm{z}$ dostopom za ljudi na invalidskih vozičkih), skupna stanovanja za mlade pare - začetna stanovanja - in eksperimentalna naselja $\mathrm{v}$ predmestju z ekonomsko funkcijo, vile (nadstandardni bloki) in sodobne družinske hiše za mesto, predmestje in podeželje. Trenutno največ gradijo družinske hiše, vendar lahko pričakujemo tudi obuditev gradnje stanovanjskih blokov in hiš za oddajanje $\mathrm{v}$ najem. Sodobni koncept zadnjih dveh oblik bo omogočil višji življenjski standard ter kakovostne storitve in opremo, kakršne si družina iz srednjega dohodkovnega razreda le stežka privošči (podzemne garaže, jaške za odpadke, videonadzor, v primerjavi s četrtmi z družinskimi hišami gostejša mreža storitev, ki jih izvaja civilna družba, centri za fitnes, večja in dobro opremljena igrišča, bazeni itd.).
Urbana arhitektura mora med številnimi oblikami $\mathrm{v}$ novih razmerah poiskati oblike simbioze nizkih najemniških stavb in družinskih hiš, in sicer na področju novogradenj ter prenove in posodobitve mest in mestnih središč. Doslej sta bili taka gradnja in prenova razdrobljeni, nestrokovni in brez primernega koncepta. Arhitekti, pristojni na državni upravi, samoupravna telesa, oddelki za gradnjo in razvoj, civilni uradi mest in mestnih občin se morajo na nove naloge ustrezno odzvati.

\section{Posledice življenja $\mathrm{v}$ naseljih $\mathrm{z}$ nizkimi stavbami}

Sklepi številnih raziskav so, da nizke družinske hiše ugodno vplivajo na način življenja in sestavo človekovih dejavnosti, na družbena razmerja ter razmerja do okolja in na zadovoljstvo z življenjskimi razmerami. Bivanje $\mathrm{v}$ nizkih stavbah $\mathrm{z}$ marsičim vpliva na njihove uporabnike ter na številne druge elemente in vidike, ki oblikujejo njihov način življenja.

Stanovanje vpliva na vso družino, na njene dejavnosti in vrednote. Večji prostori, večja zasebnost in stik z zelenimi površinami omogočajo nemoteno družinsko življenje in razvoj vzajemnega sobivanja. Koristijo posameznim članom gospodinjstva, zlasti družinam z majhnimi otroki. Terase, vrtove in atriji so "zelene« sobe, povezane $z$ notranjim bivalnim prostorom. Celota je optimalno okolje za družino, za njene dejavnosti v izobraževanju, službi in rekreaciji.

Zaradi tega se spremenijo prostočasne dejavnosti. Ljudje posvečajo čedalje več časa rekreaciji, na primer na vrtu, in so družabnejši (več se družijo s prijatelji, sorodniki in znanci), posvečajo pa se tudi aktivnemu oddihu, zato se zmanjša zanimanje za pasivno spremljanje športnih dogodkov in drugega razvedrila ter za posedanje $\mathrm{v}$ gostilnah in restavracijah. Taka stanovanja izpolnjujejo željo po soodločanju pri ustvarjanju videza in tlorisa posameznikovega bivanjskega okolja, zato se zmanjša tudi zanimanje za gradnjo in vzdrževanje vikendov.

Nizke stanovanjske stavbe ustvarjajo dobre razmere za posvečanje družinskemu življenju, zato se podaljša čas, ki ga ljudje posvečajo dejavnostim v gospodinjstvu. Stanovalci preživijo več prostega časa v kraju bivališča in tako zmanjšujejo število opravljenih poti.

Tloris nizkih stanovanjskih stavb omogoča tako zadovoljitev številnih življenjskih potreb in tak razvoj interesov posameznih družinskih članov, ki je 
za sosede nemoteč, zato se izboljšajo odnosi med sosedi. Tudi zato lahko pričakujemo razvoj sosesk z nizkimi stavbami. Pokažeta se tudi vpliv dolgega bivanja $\mathrm{v}$ istem stanovanju in socialna struktura prebivalstva, ki jo določajo stanovanja, ukrojena po meri posameznih poklicnih skupin itd. $\mathrm{V}$ takih soseskah lahko pričakujemo, da bodo sosedje komunicirali med sabo, si pomagali, izmenjavali podatke in bili vljudni drug do drugega. Zaradi dobrega družbenega razpoloženja se krajani čustveno navežejo na kraj, sosesko in okolico hiše. Poenačijo/identificirajo se s krajem bivanja. Za taka okolja so značilni stalni prebivalci, prebivalci, ki se selijo manj kot tisti, ki živijo v drugačnih stanovanjskih zgradbah.

Možnost za ustvarjalne dejavnosti in soustvarjanje ter zaščita napol javnih in napol zasebnih prostorov spodbuja stanovalce $\mathrm{k}$ dejavnemu vključevanju $\mathrm{v}$ življenje soseske. Te prostore uporabljajo pogosteje, bolj pa jih zanimajo tudi njihova nega, vzdrževanje in zaščita. Razumske, vendar času prilagojene rešitve tlorisov in pritličja spodbujajo izrabo okolice za kratkotrajno rekreacijo, druženje, športne dejavnosti in otroška igrišča. To so osnovni pogoji za razvoj intimnih prostorov, zamejenih z vidnimi in simbolnimi pregradami, ki povečujejo varnost uporabnikov, zlasti otrok.

Prilagodljive in raznovrstne rešitve strukture in tlorisa stanovanj bodo omogočile lažje prilagajanje različnim poklicnim skupinam in slojem prebivalstva. Ta oblika stanovanj lahko postane zanimiva za različne socialne skupine $\mathrm{z}$ različnim položajem $\mathrm{v}$ delitvi dela, $\mathrm{z}$ različno stopnjo izobrazbe ter z različnimi potrebami, povezanimi $\mathrm{z}$ bivanjskim in stanovanjskim prostorom. Nizke stanovanjske stavbe omogočajo tako zelo želeno združitev s posameznimi oblikami poslovnih dejavnosti, ki ne obremenjujejo okolja. To lahko zmanjša delitev dela $\mathrm{v}$ mestu in obseg prometa med posameznimi deli mesta. Življenje $\mathrm{v}$ naselju $\mathrm{z}$ nizkimi stavbami omogoča kratkotrajno rekreacijo in razbremenitev stresa, ki ga povzroča delo. Izravnava pa tudi nekatere pomanjkljivosti življenja v velikih mestih.

Prevozne in socialne storitve so $\mathrm{v}$ območjih $\mathrm{z}$ nizkimi stanovanjskimi stavbami zaradi večjih prostorskih zahtev navadno slabše. Oddaljenost do distribucijskih sistemov, šol, vrtcev, servisov in zdravstvenih domov je ponavadi veliko večja, zato je varnost $\mathrm{v}$ prometu slabša, zlasti za otroke, matere $z$ otroki in starostnike. Tudi zato je število anketirancev, ki so zadovoljni s ponujenimi socialnimi storitvami, veliko manjše. Rešitev so morda socialne storitve, kakršne so na voljo v stanovanjskih blokih.

\section{Sklep}

Opisani gospodarski ter družbeni trendi in stanovanjske potrebe izražajo potrebo po ohranitvi sedanjih oblik stanovanjskih blokov v njihovi mestni in predmestni različici ter družinskih hiš (zlasti zaradi povečane gostote in urbane ekonomije stanovanj, ki zagotavlja večje prostorsko udobje in večjo uporabnost, ohranja pa tudi odprte prostore $\mathrm{v}$ velikih mestih). To je povezano z iskanjem in vnovičnim odkrivanjem starih oblik stanovanjskih blokov $\mathrm{z}$ moderno obliko (grič, gruča in prehod), ki ima značilnosti družinskega doma. Nov pristop pomeni tudi več vrst stanovanjskih stavb, ki ustrezajo povečanemu obsegu človekovih potreb, urbanim situacijam in okoljskim zahtevam. Potrebna je tudi sprememba zakonodaje - veljavni stanovanjski zakon ne vsebuje marsikatere izmed nenavadnih, vendar primernih rešitev. Višji standard je povezan z večjim bivalnim prostorom, novo opremo in pohištvom, $\mathrm{s}$ kakovostno tehnologijo, kakovostnimi površinami itd. V stanovanjskih stavbah se pojavlja tudi povpraševanje po prostorih, ki niso namenjeni bivanju, na primer po delavnicah in prostorih za razvoj prostočasnih dejavnosti. To pa zahteva višje standarde za vhode, okolico stanovanjskih stavb itd.

Velika je tudi potreba po stanovanjskih stavbah za različne vrste prenove in za revitalizacijo uničenih delov mesta, t. i. rjavih polj. Povezava s socialnimi storitvami omogoča prihranek pri javnem prevozu, ohranja okolje, varčuje z zazidljivimi zemljišči, naložbenimi skladi, delovno silo, drago opremo in zagotavlja cenejše vzdrževanje. Omogoča tudi nove možnosti arhitekturne kompozicije in krepi privlačnost večnamenskih prostorov. Samoumevno pa je, da je odstranitev arhitekturnih ovir nujna za izboljšanje kakovosti življenja invalidov, mater z vozički, otrok in starostnikov.

\footnotetext{
Dr. Karel Schmeidler, univ. dipl. inž. arh., izredni profesor

Architectural Transport Research Centre Brno

E-pošta: schmeidler@ cdv.cz

\section{Opombe}

[1] Leta 1969 so bili na svetu registrirani samo štirje računalniki z internetnim naslovom. Deset let pozneje jih je bilo približno sto, leta 1989 se je njihovo število povečalo na 100.000 , zdaj pa je takih računalnikov več kot 60 milijonov.

[2] Delovni teden naj bi se skrajšal za dve do štiri ure. Številne zahodnoevropske države so na primer že sprejele 36-urni delovni teden.
}

Viri in literatura

Bahrdt, H. (1974) Changing structures, functions, and townscape; The transformation of a middle-sized city in Thuringia. Journal of Housing and the Built Environment.

Heidegger, M. (2002) Bytí a čas. Praha, Oikoymenh. 